\title{
Successful treatment of type III atresia ani and rectovaginal fistula in a kitten
}

\author{
Succesvolle behandeling van type III atresia ani en rectovaginale fistel bij een kitten
}

\author{
${ }^{1}$ B. Kibar Kurt, ${ }^{2}$ G. Turan
}

${ }^{1}$ University of Aydin Adnan Menderes, Faculty of Veterinary Medicine, Surgery Department, Aydın, Turkey

https://orcid.org/0000-0002-1490-8832

${ }^{2}$ Gazi Veteriner, Veterinary Clinic, Izmir, Turkey

https://orcid.org/0000-0002-1808-6573

busrakibar@yandex.com / busra.kibar@adu.edu.tr

\begin{abstract}
$\Lambda_{\text {bstract }}$
A six-weeks-old, female kitten presented with dehydration, depression, atresia ani and a discharge of watery feces from the vulvar opening. On radiographic examination, the blind-end of the rectum was determined to be $>1 \mathbf{c m}$ cranial from the anal dimple, classifying it as type III atresia ani. Atresia ani combined with a rectovaginal fistula is an uncommon congenital defect of the terminal rectum and anus that can occur in kittens. After supportive medical treatment for three days, the patient was strong enough for surgical correction. The distal rectal pouch was connected to the unperforated anus and the rectovaginal fistula was closed. The kitten recovered uneventfully and was able to defecate normally at 38 weeks follow-up. In this case report, the importance of early surgical correction to avoid potential life-threatening complications from this congenital abnormality is demonstrated.
\end{abstract}

\section{SAMENVATTING}

Een zes weken oud, vrouwelijk kitten werd aangeboden met uitdrogingsverschijnselen, depressie, atresia ani en een waterige ontlasting uit de vulva. Bij radiografisch onderzoek werd vastgesteld dat het blinde uiteinde van het rectum zich $>1 \mathrm{~cm}$ craniaal van de anatomische aanleg van de anus bevond, wat als type III atresia ani geclassificeerd kon worden. Atresia ani in combinatie met een rectovaginale fistel is een zeldzame, aangeboren afwijking van het terminale rectum en de anus bij kittens. Na drie dagen ondersteunende medische behandeling was de patiënt sterk genoeg voor chirurgische correctie. Het blind-eindigende rectum werd aangesloten op de niet-geperforeerde anus en de rectovaginale fistel werd gesloten. Het kitten herstelde zonder problemen en was in staat normaal te defeceren (laatste controle op 38 weken). In deze casuïstiek wordt het belang aangetoond van vroege chirurgische correctie om mogelijke levensbedreigende complicaties door deze aangeboren afwijking te voorkomen.

\section{INTRODUCTION}

Congenital abnormalities of the rectum and anus are uncommonly encountered in cats. The true incidence is unknown due to neonatal and postpartum deaths occurring before diagnosis and the possibility of treatment, and thus the lack of reporting (Wykes and Olson, 2003). The cloaca is a common duct for the urinary, gastrointestinal and reproductive tracts in the embryo. As a result of abnormal development of the cloaca in the embryonic period, congenital anomalies may be formed in the anus and rectum of kittens. Four types of atresia ani have been classified in small animals (Wykes and Olson, 2003; Vianna and Tobias, 2005; Ellison and Papazoglou, 2012). Type I atresia ani is a congenital stenosis of the anus. In type II atresia ani, the anal membrane persists and the rectum terminates immediately cranial of the unperforated anus 


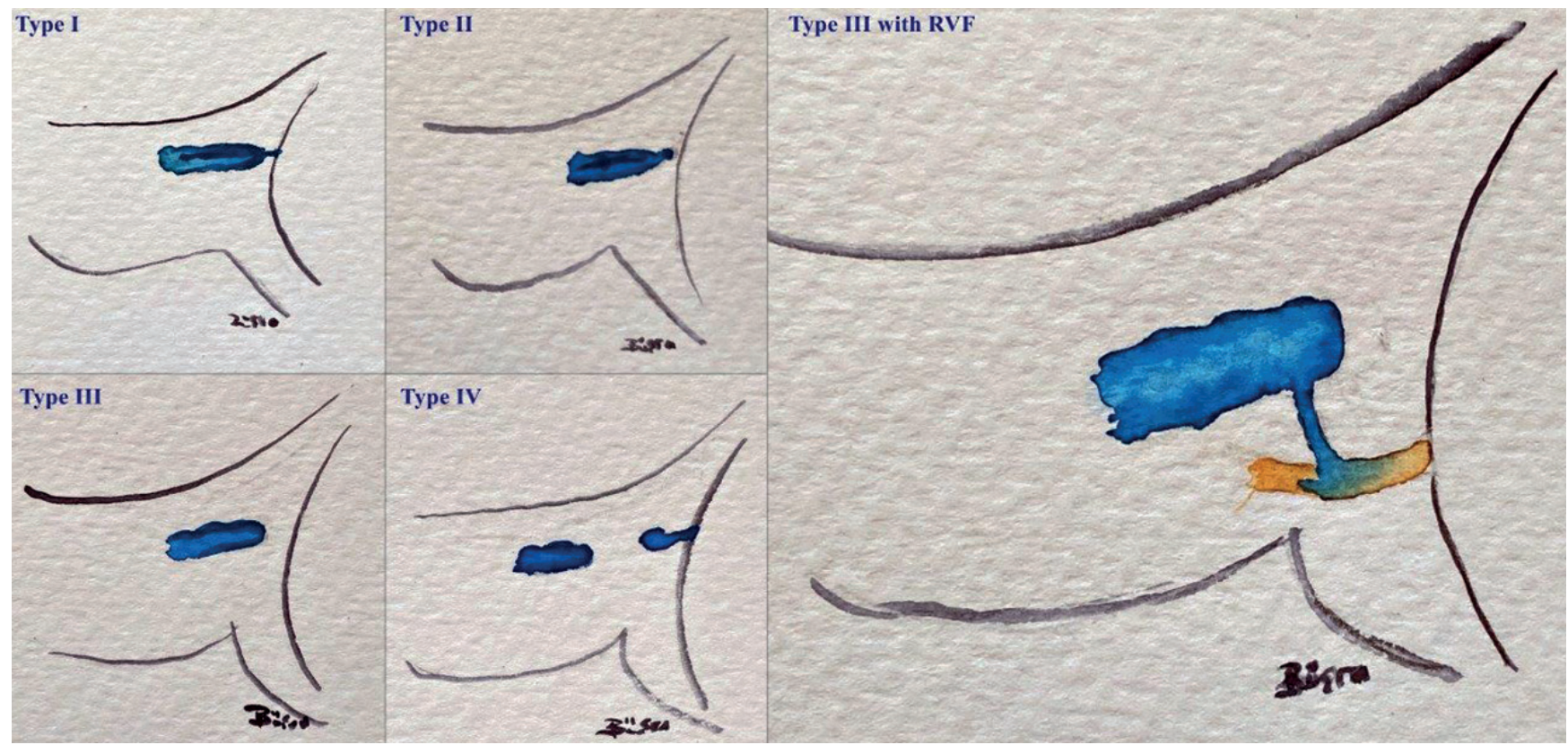

Figure 1. Schematic representation of the atresia ani types and type III atresia ani with rectovaginal fistula (RVF).

in the form of a blind pouch. In type III, the anus is closed and the blind end of the rectum is more cranial. In type IV atresia ani, the anus and terminal rectum are normally developed, but the cranial rectum terminates as a blind pouch within the pelvic canal is present (Figure 1). The presence of a rectovaginal fistula in female cats occurs occasionally in type II atresia ani and rarely in type III atresia ani (Suess et al., 1992; Peña and Hong, 2000; Wykes and Olson, 2003; Chandler and MacPhail, 2001; Ellison and Papazoglou, 2012). Rectovaginal fistulas are associated with failure in the embryonic cloaca section of the urorectal fold. The fistula joins the dorsal wall of the vagina with the ventral terminal rectum, which generally terminates as a blind pouch (Suess et al., 1992). The fistula allows evacuation of feces and hence the animal survives the postpartum period.

In this case report, a kitten is described with the uncommon combination of type III atresia ani and

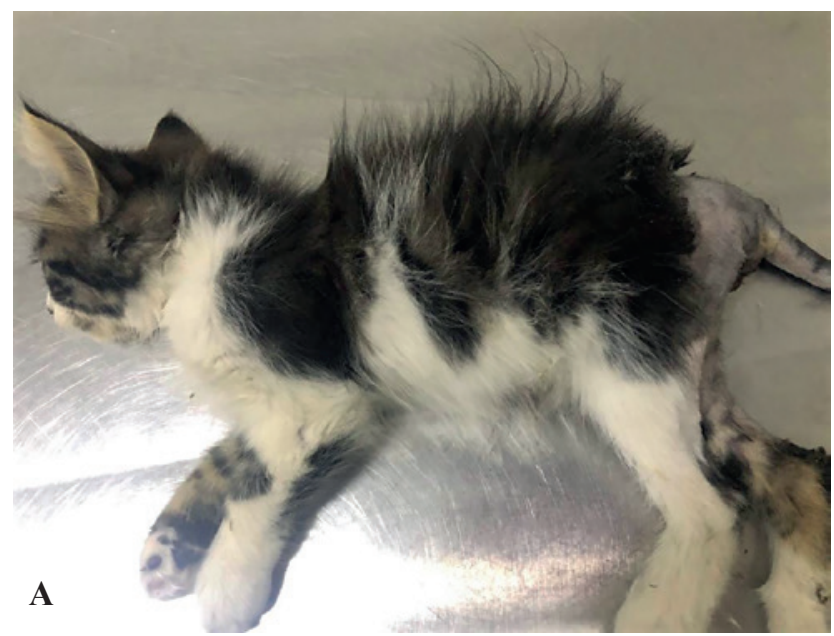

rectovaginal fistula, which was successfully treated with surgery.

\section{CASE PRESENTATION}

A six-weeks-old, intact, female mixed breed cat of $800 \mathrm{~g}$ was presented to the Surgery Department of the Aydin Adnan Menderes University, Faculty of Veterinary Medicine, Turkey. The anamnesis consisted of painful urination and previous treatment for cystitis by the referring veterinarian. Urinary or fecal incontinence was not observed by the owner in the first weeks. The kitten presented in lateral recumbency, had anorexia, impaired development, abdominal swelling, and was apathic (Figures 2A and 2B). On clinical examination, no anal opening was detected; feces were released from the vulva with accompanying ulceration of the labia due to feces. Radiography

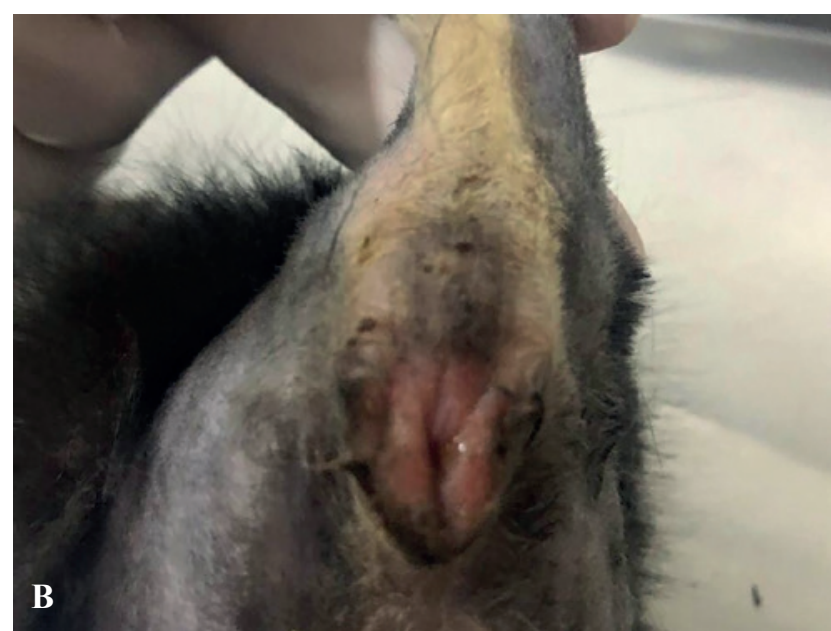

Figure 2. A. Six-weeks-old kitten in lateral recumbency. B. Detail of the perineal area illustrating the ulceration of the labia due to fecal evacuation from the vulva and the absence of an anal opening. 
and retrograde contrast fistulography identified type III atresia ani with rectovaginal fistula (Figure 3). Medical treatment was applied for three days to improve the cat's general condition. Fluid therapy with Ringer's lactate was instituted to correct dehydration, and some of the impacted feces were evacuated out of the vulva by giving an enema from the fistula to the rectum with a catheter (Libalaks $53,1 \%+37 \%$ rectal gel, Turkey) and broad spectrum antibiotic therapy. Sulfadiazine Sodium/Trimethoprim $(16 \mathrm{mg} / \mathrm{kg}$, once a day, Ba-Sülfa TMP, BaVET, Turkey) for seven days and Metronidazole for five days $(20 \mathrm{mg} / \mathrm{kg}$, twice daily, Flagyl $500 \mathrm{mg} / 100 \mathrm{ml}$ intravenous infusion, Aventis, France) were used in the antibiotic therapy.

Induction consisted of the combination of $1 \mathrm{mg} / \mathrm{kg}$ ketamine (Ketasol 10\%, Richter Pharma Ag, Austria), $0.1 \mathrm{mg} / \mathrm{kg}$ butorphanol (Butomidor $10 \mathrm{mg} / \mathrm{ml}$, Richter Pharma Ag, Austria) and $0.01 \mathrm{mg} / \mathrm{kg}$ medetomidine (Domitor $1 \mathrm{mg} / \mathrm{ml}$, Zoetis, USA) administered intravenously. Following endotracheal intubation, general anesthesia was applied with $2 \%$ isoflurane (Isoflurane USP, Piramal Critical Care, USA) in an oxygen mixture.

The kitten was positioned in sternal recumbency with the pelvis elevated, the pelvic limbs hanging over the end of the table, and the tail fixed over the back. The perineal area was disinfected and draped according to current standards. An incision (approximately $1.5 \mathrm{~cm}$ ) was made over the anal dimple, where the anus should have been located anatomically. The perineal soft tissues were retracted to access the distal rectal pouch. This was brought out through the incision, then opened and sutured to the surrounding skin using interrupted sutures of a 3-0 multiflament, absorbable suture material (Vicryl, Ethicon, USA). The location of the rectovaginal fistula was determined by inserting a curved-tip hemostatic forceps in the vagina. An episiotomy incision (no more than $1 \mathrm{~cm}$ ) was made to connect the vulvar opening to the anal dimple for access to the fistula. The fistula was cut in the middle and both rectal and vaginal borders were closed with interrupted sutures of a 4-0 monofilament

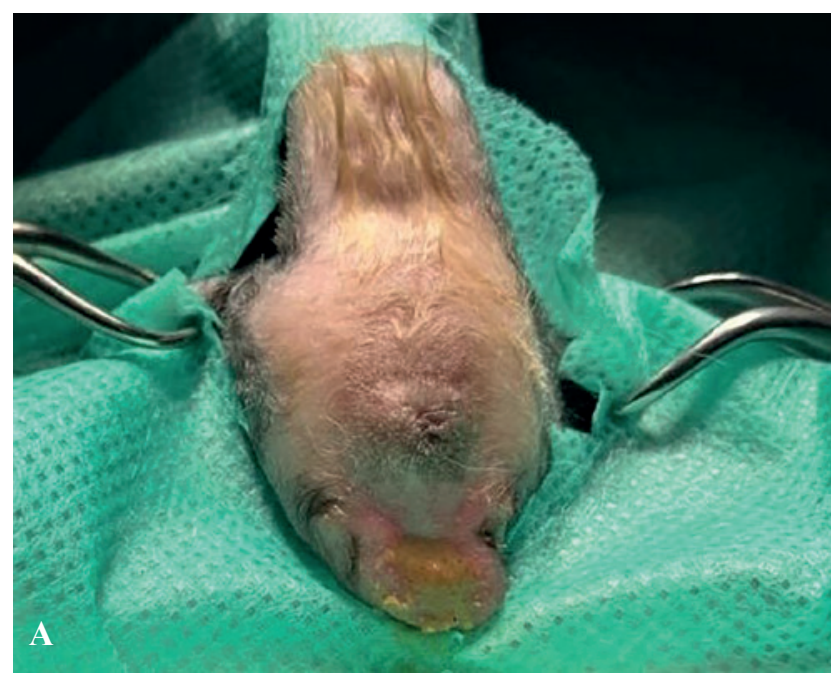

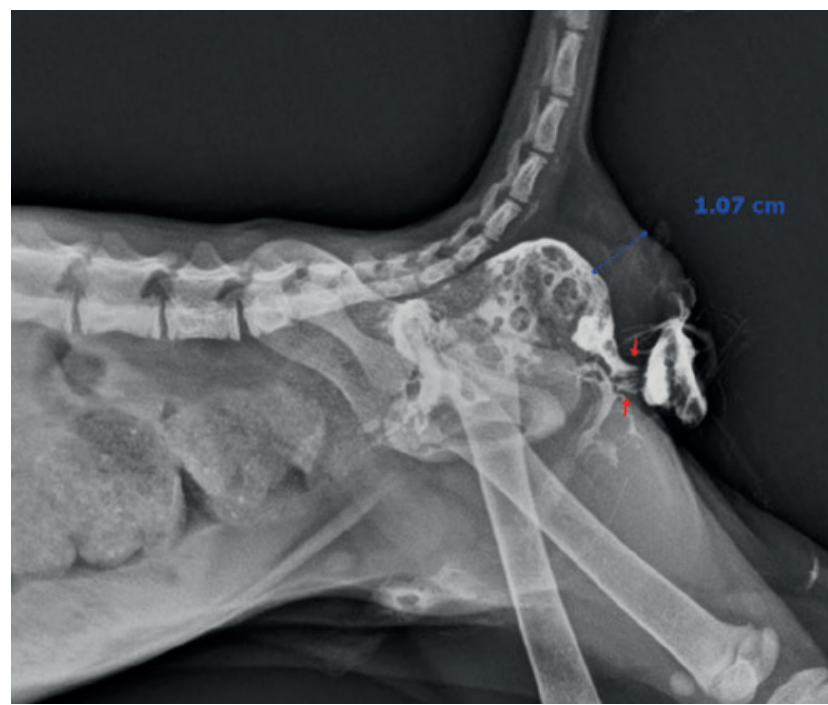

Figure 3. Lateral plain positive contrast radiograph, The blind rectal pouch is $1.07 \mathrm{~cm}$ away from the anal dimple (Blue interrupted line). Red arrows: Rectovaginal fistula.

absorbable suture material (Monosorb, Sutured Ltd., United Kingdom) (Figures 4A and 4B).

Recovery was unremarkable and the cat started eating as soon as she was fully awake. Tinned cat food (Hill's A/D) was given on the first day, and Hill's biome cat food the next three days. To improve evacuation of feces, $2 \mathrm{ml} / \mathrm{kg}$ Duphalac (Abbott $670 \mathrm{mg}$ / $\mathrm{ml}$, Illinois, USA) was given. The perineal area was cleaned three to four times daily. The sutures were removed on postoperative day 15 . The cat presented for a follow-up control on day 122. A normal bodyweight of $2.5 \mathrm{~kg}$ was noted. There were no defecation problems. Feces were evacuated without straining, there was no fecal incontinence and no discharge from the vulva or symptoms suggesting cystitis were observed. It was determined that there were no general condition disorder and no painful urination. The owner was contacted by phone when the cat was 38 weeks old and he informed that she was healthy.

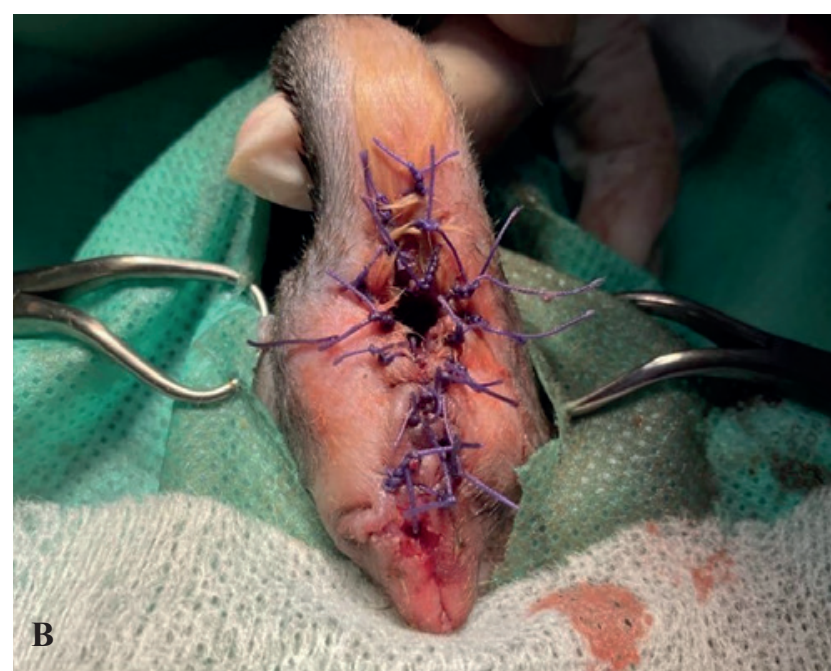

Figure 4. A end B. Preoperative and postoperative images of anoplasty and episiotomy. 


\section{DISCUSSION}

Most animals with atresia ani are euthanized or die in the immediate postpartum period. Combined with a rectovaginal fistula however, fecal evacuation occurs from the vagina. In the care of the mother cat, who regularly cleans the perineum, this condition might even remain undiagnosed till a later age. This may be the reason why the owner in this case did not notice fecal incontinence in the first weeks. As the kitten grows up, clinical symptoms become evident due to ascending cystitis or fecal obstruction. The described patient had been treated for cystitis and was presented at on older age with severe abdominal distension and the resulting lateral recumbency, anorexia, impaired development and apathy. Whilst small amounts of watery feces can pass through the fistula and exit the vulva, leading to secondary ulceration of the labia, firmer feces cannot pass the fistula and remain in the colon, resulting in abdominal distention (Vianna and Tobias, 2005; Rahal et al., 2007). On radiographic examination, this was easily identified. Colonic obstruction results in metabolic abnormalities that become evident as anorexia and lethargy, and ultimately death of the patient.

The differentiation between type II and type III atresia ani is made on the presence of the rectal blind pouch immediately adjacent to the unopened anus or a radiographic distance of $>1 \mathrm{~cm}$ away from it, respectively (Vianna and Tobias, 2005). This distance is thought to represent either an unopened anus with the distal rectum next to the skin $(<1 \mathrm{~cm})$, or the absence of the terminal part of the rectum $(>1 \mathrm{~cm})$. Contrast radiographic examination in the present case identified the distal rectal pouch to be more than $1 \mathrm{~cm}$ away from the anal dimple. Surgical reconstruction therefore requires more than a simple anoplasty. The distal rectum needs to be dissected and brought in tensionless contact with the skin. Afterwards, it is essential to close the fistula by transecting it and suturing both ends (Louw and van Schouwenburg, 1982; Prassinos et al., 2003; Wykes and Olson, 2003; Mahler and Williams, 2005; Vianna and Tobias, 2005; Rahal et al., 2007; Ellison and Papazoglou, 2012). An alternative technique, described by Jardel et al. (2013) consists of using the fistula to bridge the distance from the distal rectal pouch to the anus. In this case, the authors first performed an anoplasty from a vertical incision over the anal dimple as described by Wykes and Olson (2003). Afterwards, they succeeded in mobilizing the distal rectum, not requiring additional tissue from the fistula. The rectovaginal fistula was then transected as described by Mahler and Williams (2005). Immediately after the procedure, the presence of a patent rectum was evident from a ravenous appetite, easy passage of feces and continued weight gain. In follow-up control, an anal sphincter and an active fecal continence mechanism were noted.

Atresia ani in kittens may be accompanied by other congenital anomalies, such as sacrocaudal dys- genesia and even hydrocephalus (Suess et al., 1992; Ellison and Papazoglou, 2012). These should not be overlooked in a thorough physical or other diagnostic examination. Rectocutaneous fistulas associated with type II atresia ani have been reported in a cat (Tsioli et al., 2009).

Positive contrast vaginography was applied in the patient of the present case and the passage of contrast material to the intestine was observed on radiography. Vaginography and fistulography are indispensable in the localization of the fistula and the terminal rectum (Prassinos et al., 2003; Vianna and Tobias, 2005; Rahal et al., 2007; Ellison and Papazoglou, 2012). In a previous retrospective study, two out of three puppies with type III atresia ani had complications or clinical signs after surgery and were euthanized at three and forty days postoperatively (Ellison and Papazoglou, 2012). In the light of these reports and despite the small number of cases, it was concluded that the prognosis is more unfavorable in case of type III atresia ani. The presented case had a long-term successful outcome with preoperative medical treatment and appropriate surgical correction.

\section{CONCLUSION}

In the literature, information on the prognosis after treatment of atresia ani is sparse since the condition is underreported due to postpartum death when the condition goes unnoticed. In this case, adequate medical stabilization and surgical correction in case of type III atresia ani with a rectovaginal fistula were successful and resulted in a long-term normal function of the rectum.

\section{REFERENCES}

Chandler JC, MacPhail CM. (2001). Congenital urethrorectal fistulas. Compendium on Continuing Education for the Practicing Veterinarian 23, 995-1002.

Ellison GW, Papazoglou LG. (2012). Long-term results of surgery for atresia ani with or without anogenital malformations in puppies and a kitten: 12 cases (1983-2010). Journal of the American Veterinary Medical Association 240, 186-192.

Jardel N, Vallefuco R, Viateau V. (2013). A fistula flap technique for correction of type 11 atresia ani and rectovaginal fistula 6 kittens. Veterinary Surgery 42, 180-185.

Louw GJ, van Schouwenburg SJ. (1982). The surgical repair of atresia ani in a Dobermann bitch. Journal of the South African Veterinary Association 53, 119-120.

Mahler S, Williams G. (2005). Preservation of the fistula for reconstruction of the anal canal and the anus in atresia ani and rectovestibular fistula in 2 dogs. Veterinary Surgery, 34, 148-152.

Peña A, Hong A. (2000). Advances in the management of anorectal malformations. The American Journal of Surgery, 180, 370-376.

Prassinos NN, Papazoglou LG, Adamama-Moraitou KK, 
Galatos AD, Gouletsou P, Rallis TS. (2003). Congenital anorectal abnormalities in six dogs. Veterinary Record 153, 81-85.

Rahal SC, Vicente CS, Mortari AC, Mamprim MJ, Caporalli EHG. (2007). Rectovaginal fistula with anal atresia in 5 dogs. Canadian Veterinary Journal 48, 827-830.

Wykes PM, Olson PN. (2003). Vagina, vestibule, and vulva. In: Slatter DH. (editor). Textbook of Small Animal Surgery. Elsevier Health Sciences, Philadelphia, p. 15021510.

Suess RP, Martin RA, Moon ML, Dallman MJ. (1992). Rectovaginal fistula with atresia ani in three kittens. The Cornell veterinarian 82, 141-153.

Tsioli V, Papazoglou LG, Anagnostou T, Kouti V, Papado- poulou P. (2009). Use of a temporary incontinent end-on colostomy in a cat for the management of rectocutaneous fistulas associated with atresia ani. Journal of Feline Medicine and Surgery 11, 1011-1014.

Vianna ML, Tobias KM. (2005). Atresia ani in the dog: A retrospective study. Journal of the American Animal Hospital Association 41, 317-322.

2021 by the authors. Licensee Vlaams Diergeneeskundig Tijdschrift, Ghent University, Belgium. This article is an open access article distributed under the terms and conditions of the Creative Commons Attribution (CC BY) license (http://creativecommons.org/licenses/by/4.0/).

\section{Casussen uit de praktijk in het Vlaams Diergeneeskundig Tijdschrift}

Beste collega,

Omdat het Vlaams Diergeneeskundig Tijdschrift in de eerste plaats een tijdschrift van en voor dierenartsen is, wil de redactieraad een oproep doen om bijzondere gevallen die u in uw praktijk ziet, kenbaar te maken in de vorm van een artikel dat in het tijdschrift na beoordeling gepubliceerd kan worden.

Geïnteresseerden worden voor de opmaak van hun case report aangeraden de richtlijnen voor auteurs te volgen: https://ojs.ugent.be/vdt/guidelines of kunnen terecht bij nadia.eeckhout@, ugent.be

Als voorbeeld kunnen de vier casuïstieken dienen die in dit nummer werden opgenomen.

Luc Peelman,

Hoofdredacteur 